\author{
Viktor Shevchuk \\ Cracow University of Technology \\ e-mail:vshevchuk@pk.edu.pl \\ ORCID: 0000-0002-7125-1267
}

\title{
MACROECONOMIC EFFECTS OF OUTPUT VOLATILITY IN UKRAINE
}

\section{EFEKTY MAKROEKONOMICZNE ZMIENNOŚCI PRODUKCJI W GOSPODARCE UKRAINY}

DOI: $10.15611 / \mathrm{pn} .2019 .12 .09$

JEL Classification: C22, E32, O40

Summary: This paper focuses on several macroeconomic effects of the output volatility in Ukraine. Our findings suggest that the volatility that originates from the gross domestic product (GDP) has a sizeable, negative and statistically significant effect on economic growth and investments while being complementary to industrial production (no impact on consumption and consumer prices has been detected). The results also indicate asymmetric exchange rate effects upon GDP and industrial production growth. Among other results, it has been found that (i) output volatility has expansionary effects on three out of five sectors (manufacturing, food processing and power generation), with a likely contractionary effect on the steel-making industry, (ii) exchange rate depreciation stimulates investments, but at the expense of higher inflation and lower consumption, (iii) output volatility is associated with lower money supply and a decrease in the interest rate, with a negative impact on the budget balance.

Keywords: GDP volatility, economic growth, exchange rate, Ukraine.

Streszczenie: W niniejszym opracowaniu oszacowano wpływ zmienności wzrostu produkcji na wybrane wskaźniki makroekonomiczne dla gospodarki Ukrainy. Ustalono, że większa zmienność produktu krajowego brutto (PKB) oddziałuje negatywnie (na poziomie istotności statystycznej) na wzrost gospodarczy oraz inwestycje, w tym opisano, jak zmienność PKB jest korzystna dla produkcji przemysłowej (jednocześnie nie ma wpływu na konsumpcję oraz ceny konsumenckie). Otrzymane rezultaty świadczą o asymetrycznym oddziaływaniu kursu walutowego na wzrost PKB oraz produkcji przemysłowej. Dowiedziono także, że: (i) zmienność PKB powoduje zwiększenie produkcji w trzech z pięciu branży przemysłowych (wytwórczość, przetwórstwo rolno-spożywcze oraz energetyka) oraz iż negatywny wpływ na dynamikę produkcji dostrzega się najprawdopodobniej wyłącznie w hutnictwie, (ii) deprecjacja kursu walutowego powoduje zwiększenie inwestycji, ale kosztem przyśpieszenia inflacji oraz spadku konsumpcji, (iii) większa zmienność produkcji kojarzy się ze zmniejszeniem podaży pieniądza oraz obniżeniem poziomu stopy procentowej przy jednoczesnym pogorszeniu się bilansu budżetowego.

Słowa kluczowe: zmienność PKB, wzrost gospodarczy, kurs walutowy, Ukraina. 


\section{Introduction}

Output volatility is a distinct feature of Ukraine's economy, widely seen among the most important explanations of its stagnant economic growth. Starting with the seminal paper by Ramey and Ramey (1995), it is a well-established fact in crosscountry studies that countries with higher volatility of output have lower GDP growth rates (Hnatkovska \& Loayza, 2005; Aghion, Angeletos, Banerjee, \& Manova, 2010; Posch, 2011; Antonakakis \& Badinger, 2016). Similar results have been obtained in country-specific studies for European Union countries (Güreşçi, 2018). In comparison to the U.S. and other developed countries, uncertainty shocks have stronger negative effects on emerging economies (Carrière-Swallow \& Céspedes, 2013). However, time series methods do not rule out the possibility of a positive link between output volatility and output growth (Caporale \& McKiernan, 1996). Several studies have indicated that the relationship between volatility and economic growth is not linear (Alimi, 2016; Garcia-Herrero \& Villarubia, 2007). There are also studies that imply no causality between output volatility and output growth, as was proved for Japan (Fountas, Karanasos, \& Mendoza, 2004) and the U.K. (Speight, 1999). Empirical evidence suggesting that volatility reduces investment can be seen in many crosssection studies (Hoffmann, Krause, \& Tillmann, 2019; Gete \& Melkadze, 2018), as well as with reference to country-specific time series, as in the case of Turkey (Berument, Dincer, \& Mustafaoglu, 2012).

Provided that theoretical consensus is non-existent, the analysis of the relationship between output variability and economic growth remains an empirical issue (Fountas et al. 2004). Macroeconomic theory offers three possible scenarios regarding the impact of output variability on output growth: (i) negative (volatility affects investment and growth due to unfavourable effects of uncertainty), (ii) positive (volatility contributes to higher savings and investment in riskier technologies), (iii) neutral stance (volatility is caused mainly by price misperceptions).

This paper aims at contributing to the debate on the links between output volatility and economic growth by means of an empirical analysis of data for Ukraine, with important implications for stabilisation policy and macroeconomic decisionmaking. For this purpose, the autoregressive conditional heteroscedastic (ARCH) and generalized autoregressive conditional heteroscedastic (GARCH) models are estimated. The EViews software version 9.1 was used for the data analysis. The remainder of this paper is structured as follows. Section 2 outlines the main analytical arguments, Section 3 discusses the data and methods employed in the empirical analysis, Section 4 presents the empirical results, and Section 5 concludes the paper.

\section{Theoretical framework}

According to the mainstream view, output volatility is associated with uncertainty, inefficient resource allocation, higher prices and lower growth rates. As mentioned by Carrière-Swallow and Céspedes (2013), as early as in the1930s J. M. Keynes 
suggested that investment was the most volatile component of aggregate demand precisely because it relies most heavily on opinions about future events, which are necessarily ill-informed. In a similar fashion, Bernanke (1983) argues that output volatility raises economic uncertainty and thus hampers investment due to its irreversible nature, thus leading to lower economic growth. However, higher volatility could increase precautionary saving and therefore contribute to higher growth rates (Lensink, Bo, \& Sterken, 1999). Similar conclusions are suggested by the optimal portfolio theory (Imbs, 2007). On the other hand, lack of correlation between output variability and growth is suggested by some Real Business Cycle (RBC) models which explain output fluctuations around the long-term trend by price misperceptions in response to monetary shocks. Although changes in the growth rate of output may arise from real factors such as technology (Friedman, 1968), the above-mentioned lack of correlation between output volatility and economic growth supports such interpretation (Fountas et al. 2004).

Within the framework of a DSGE model with nominal rigidities and the growth driven by learning-by-doing, it has been demonstrated by Annicchiarico, Corrado and Pelloni (2011) that volatility effects could be positive or negative depending on the impulse source of fluctuations. While monetary shocks volatility generally has a negative effect on growth, the opposite tends to be true for fiscal and productivity shocks. If one interprets output volatility as a proxy for productivity shocks, it explains this somewhat ambiguous empirical relationship between output volatility and economic growth.

With the application of a simple single-agent model of technology adoption, Ferrero (2017) demonstrates that economies with more volatile growth rates have higher time adoption lags for the technology diffusion and lower average growth. Assuming the existence of a frontier technology that becomes available for adoption, the replacement of the old technology entails a substantial sunk cost and it is irreversible. Sunk costs and investment irreversibilities are viewed as key determinants of the diffusion of large-scale technologies such as major information and communication technologies. Therefore, decisions concerning technology are determined by the risk-return trade-off, with uncertainty about the returns to technology adoption generating the real value of inaction which delays the diffusion of the higher-mean-growth frontier technology. Hence, the mean and volatility of output growth are jointly determined and negatively related in equilibrium.

Volatility is supposed to reduce productivity growth to a greater extent in sectors that depend heavily on external finance, as credit constrained firms reduce productivity-enhancing investments, such as ICTs (Aghion et al. 2010). These theoretical implications are confirmed by productivity growth estimates of 25 industries from 18 advanced economies over the period 1985-2010 (Choi, Furceri, Huang, \& Loungani, 2018). Gete and Melkadze (2018) utilize an International RBC model in order to demonstrate that higher volatility contracts credit supply and depresses investment and output. A negative link between volatility and investments is obtained by Hoffmann, Krause and Tillmann (2019), but it has been found that investment reacts to long-run volatility of GDP growth less than to consumption. 
However, there are numerous arguments proving that volatility (macroeconomic uncertainty) raises aggregate productivity growth. Oikawa (2010) presents a model with learning-by-doing in the research sector, resulting in social knowledge accumulation that improves the productivity of the future research. An increase in the level of uncertainty decreases the expected productivity in the short run, but raises the expected productivity growth rate and the expected productivity in the long run. The positive correlation between TFP growth and volatility is to be expected in manufacturing industries in the first place.

\section{Data and statistical methodology}

The data set used in this paper is quarterly data for Ukraine from 2000Q1 to 2018Q4. The time series for the GDP (in 1994 prices) and industrial production (in 1996 prices) are from the Ukrainian State Statistical Committee (Figures 1a,b). Both indicators reveal a sharp decline in output during the 2008-2009 financial crisis and again since 2014. The time series for sectoral output (Figure 1c) are obtained on the basis of weights of particular branches in total industrial production. It is worth noting that a remarkable drop in manufacturing and steel production since 2009 has been observed against the backdrop of relative stability of pre-crisis and postcrisis production levels in the food processing and power generation branches. The investment and consumption-to-GDP ratios were calculated on the basis of the IMF International Financial Statistics database (Figure 1d). The former was on the rise until the middle of 2008, but declined significantly over the last decade, while the latter oscillates around the mean of approximately $70 \%$ of GDP.

A visual inspection of the GDP series (Figure 1a) suggests that volatility was present in several periods, especially between 2008 and 2009, which is due to the world financial crisis, and between 2014 and 2016, at the beginning of the military conflict with Russia. In such cases, ARCH/GARCH models designed to deal with heteroscedasticity should be applied.

In the baseline model, the volatility applied is the estimated conditional variance of GDP from a univariate $\operatorname{GARCH}(1,1)$ model:

$$
\begin{gathered}
\Delta \ln Y_{t}=\eta+\xi_{t}, \quad \xi_{t} / \Omega_{t-1} \approx N\left(0, \sigma_{t}\right), \\
\sigma_{t}^{2}=\omega+\alpha \xi_{t-1}^{2}+\beta \sigma_{t-1}^{2}+\gamma \text { CRISIS }_{t}, \quad \omega>0, \quad \alpha \geq 0, \quad \beta \geq 0,
\end{gathered}
$$

where: $\Delta$ is the operator of the first differences, $\eta$ is the expected value modelled as $\operatorname{ARMA}(1,1)$ process of $\Delta \ln Y_{t}$ conditional on past information $\left(\Omega_{t-1}\right)$ and $\xi_{t}$ is the stochastic factor. A one-period ahead forecast variance, $\sigma_{t}$, is a function of the mean $(\omega)$, the ARCH term $\left(\xi_{t-1}^{2}\right)$, the GARCH term $\left(\sigma_{t-1}^{2}\right)$, and a dummy CRISIS for the period of 2014-2015. The covariance stationarity requires $\alpha+$ $\beta<1$. The estimated $\sigma_{\mathrm{t}}$ (conditional variance) was applied to the estimation of the determinants for macroeconomic indicators as a measure of the volatility of output. 


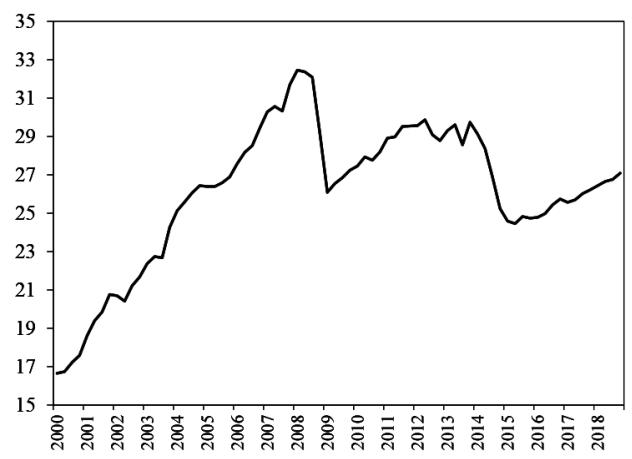

a) GDP (in 1994 prices)

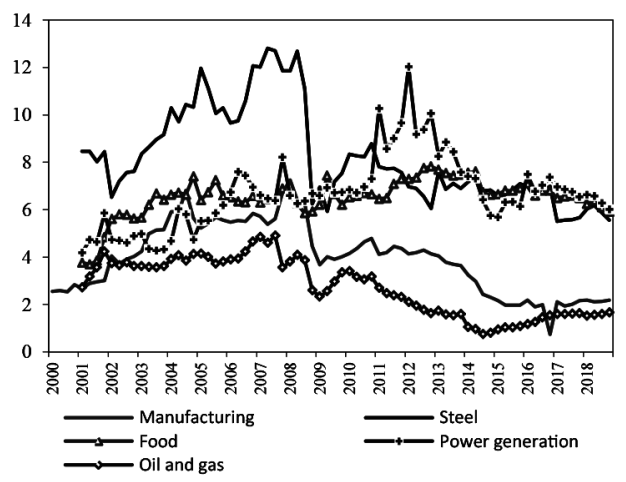

b) sectoral output (in 1996 prices)

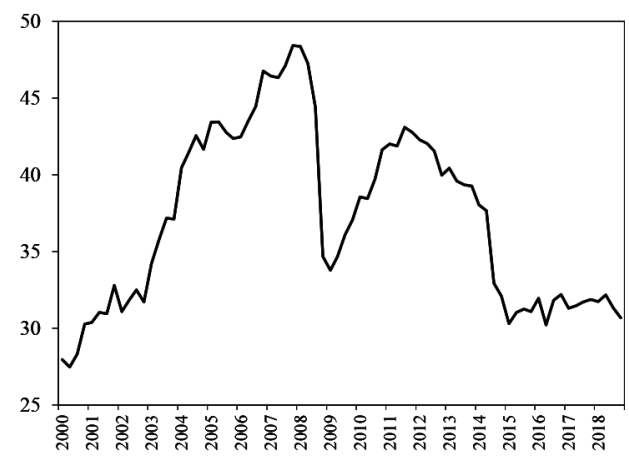

b) industrial production (in 1996 prices)

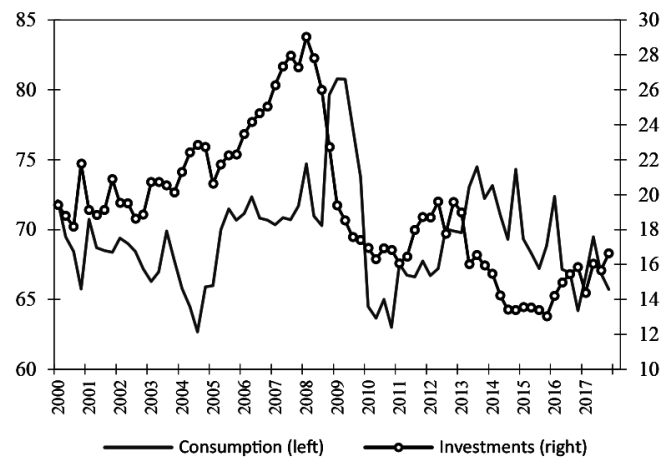

c) consumption and investment ( $\%$ of GDP)

Fig. 1. Ukraine: selected macroeconomic indicators, 2000-2018

Source: Ukraine's State Statistical Committee (www.ukrstat.gov.ua), IMF (www.imf.org).

Table 1. Univariate GARCH results

\begin{tabular}{|c|l|c|c|c|c|c|c|c|}
\hline \multicolumn{2}{|c|}{ Model } & $\eta_{0}$ & $\mathrm{AR}(1)$ & $\mathrm{MA}(1)$ & $\omega$ & $\alpha$ & $\beta$ & $\gamma$ \\
\hline ARCH(1,0) & I & $\begin{array}{c}0.015 \\
(0.95)\end{array}$ & $\begin{array}{c}0.970 \\
\left(11.10^{* * *}\right)\end{array}$ & $\begin{array}{c}-0.936 \\
\left(-6.71^{* * *}\right)\end{array}$ & $\begin{array}{c}0.0003 \\
\left(4.40^{* * *}\right)\end{array}$ & $\begin{array}{c}0.760 \\
\left(3.15^{* * *}\right)\end{array}$ & - & $\begin{array}{c}-0.0002 \\
\left(-2.75^{* * *}\right)\end{array}$ \\
\hline GARCH(1,1) & II & $\begin{array}{c}0.015 \\
\left(4.51^{* * *}\right)\end{array}$ & $\begin{array}{c}0.556 \\
\left(2.50^{* *}\right)\end{array}$ & $\begin{array}{c}-0.390 \\
(-1.20)\end{array}$ & $\begin{array}{c}0.0002 \\
\left(2.17^{* *}\right)\end{array}$ & $\begin{array}{c}0.169 \\
(1.18)\end{array}$ & $\begin{array}{c}0.621 \\
\left(4.05^{* * *}\right)\end{array}$ & $\begin{array}{c}-0.0002 \\
\left(-2.73^{* * *}\right)\end{array}$ \\
\hline
\end{tabular}

Note: $z$-statistic in parentheses; hereafter ${ }^{*},{ }^{* *},{ }^{* * *}$ imply statistical significance at the 10,5 and $1 \%$ level, respectively.

Source: author's calculations.

Table 1 presents the result from two models of output volatility. The ARCH effect is large in the $\operatorname{ARCH}(1,0)$ model, with the coefficient of $\alpha$ being statistically 
significant at the $1 \%$ level. However, the $\mathrm{ARCH}$ term is not significant in the alternative $\operatorname{GARCH}(1,1)$ model but there is a significant GARCH effect in the model as the coefficient of $\beta$ is highly significant.
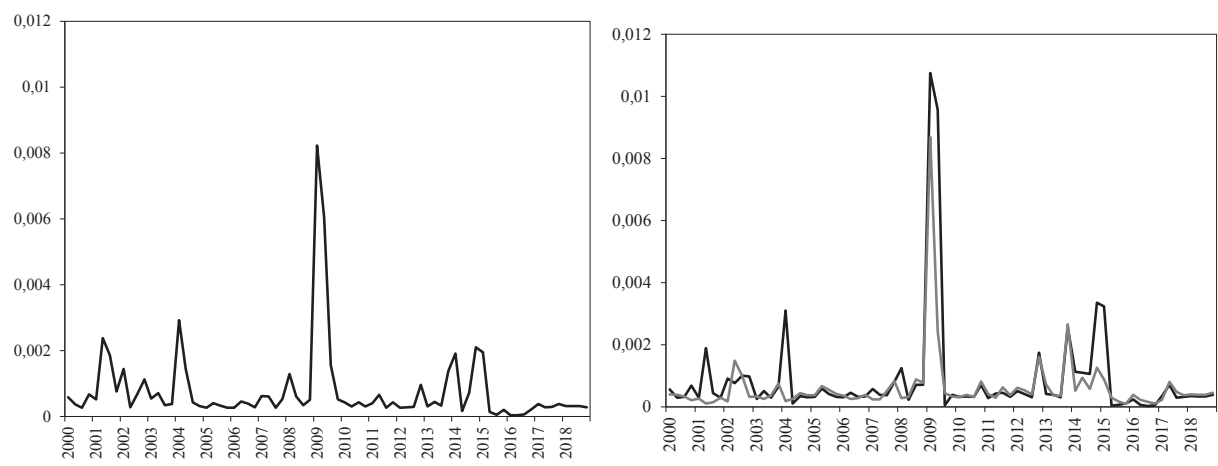

Fig. 2. Variability of output, 2000-2018

Source: author's calculations.

Variance series from $\operatorname{ARCH}(1,0)$ and $\operatorname{GARCH}(1,1)$ models are presented in Figure 2, and also variance from the $\operatorname{EGARCH}(1,1)$ model which differs from the GARCH variance structure because of the log of variance is added in order to visualize possible differences. As variances from the $\mathrm{ARCH}(1,0)$ and $\operatorname{GARCH}(1,1)$ models identify three peaks of output instability in 2001, 2004 and 2009, with a prolonged period of instability in 2012-2015, variance from the $\operatorname{EGARCH}(1,1)$ model seems to ignore the instability peaks in 2014 and 2015.

Then the statistical model for effects of output volatility is as follows:

$$
\Delta X_{t}=a_{0}+\sum_{i=1}^{n} a_{i} X_{t-1}+b_{1} \sigma_{t}+b_{2} e_{t}+b_{3} p_{t}^{C}+b_{4} \text { CRISIS }_{t}+\varepsilon_{t},
$$

where $X_{t}$ is a dependent variable, $\sigma_{t}$ is the output volatility, $e_{t}$ is a nominal exchange rate (hryvnas per US dollar), $p_{t}^{C}$ is the commodity price index $(2010=100)$, CRISIS is a crisis dummy ( 1 for 2004Q3:2004Q4, 2008Q3:2009Q3, 2013Q3:2015Q4, and 0 otherwise). In order to control for commodity prices, the aggregate price index is used in most of the cases, as provided by the IMF database (www.imf.org), even though the disaggregated price indices for metals, crude oil and wheat are used in particular specifications of the regression models as well.

The list of dependent variables includes GDP, $y_{t}$, industrial production, ind $t_{t}$ investments, invest $t_{t}$, consumption, cons, consumer prices, $c p i$, and sectoral outputs in manufacturing, ind $t_{t}^{\text {MAN }}$, steelmaking, ind $t_{t}^{\text {STEEL }}$, food processing, ind ${ }_{t}^{F O O D}$, power generation, ind $t^{\text {POWER }}$, and oil and gas extraction, ind $d_{t}^{\text {OLL }}$, branches of industry. The same set of independent variables is used in the estimation of policy reaction to 
output volatility, including such indicators as monetary aggregate $\mathrm{M} 2, m{ }_{t}$ (millions of hryvnas), budget balance, $b d_{t}$ (\% of GDP), lending and deposit interest rates, $r l_{t}$ and $r d_{t}(\%)$, respectively. Except for $b d_{t}$, all other variables are used in logs.

\section{Empirical results}

Table 2 presents the results of the 2SLS regressions for GDP $\left(y_{t}\right)$, industrial production (ind $)_{t}$ ), investment (invest $t_{t}$, consumption ( cons $)_{t}$ ) and consumer prices $\left(c p i_{t}\right)$. As for the estimates in the first differences, the coefficient of determination $R^{2}$ is rather high in all specifications, while the ADF test supports the hypothesis of stationarity of the residuals, thus confirming the adequacy of the regression models.

Table 2. Determinants of output, investment, consumption and consumer prices

\begin{tabular}{|c|c|c|c|c|c|c|}
\hline \multirow{2}{*}{$\begin{array}{l}\text { Dependent } \\
\text { variable }\end{array}$} & \multirow[b]{2}{*}{ Model } & \multicolumn{4}{|c|}{ Independent variables } & \multirow[b]{2}{*}{ Statistics } \\
\hline & & Volatility & $\begin{array}{l}\text { Exchange } \\
\text { rate }\end{array}$ & $\begin{array}{c}\text { Commodity } \\
\text { prices }\end{array}$ & $\begin{array}{l}\text { Crisis } \\
\text { dummy }\end{array}$ & \\
\hline \multirow{2}{*}{$\Delta y_{t}$} & I & $\begin{array}{c}-5.877 \\
\left(-2.02^{* *}\right)\end{array}$ & $\begin{array}{c}-0.107 \\
\left(-2.08^{* *}\right)\end{array}$ & $\begin{array}{l}-0.051 \\
\left(-1.66^{*}\right)\end{array}$ & $\begin{array}{c}-0.023 \\
\left(-2.61^{* * *}\right)\end{array}$ & $\begin{aligned} R^{2} & =0.31 \\
\mathrm{ADF} & =-8.17^{* * *}\end{aligned}$ \\
\hline & II & $\begin{array}{c}-4.772 \\
\left(-2.28^{* *}\right) \\
\end{array}$ & $\begin{array}{c}-0.132 \\
\left(-2.42^{* *}\right)\end{array}$ & $\begin{array}{c}-0.075 \\
\left(-2.16^{* *}\right) \\
\end{array}$ & $\begin{array}{c}-0.024 \\
\left(-3.01^{* * *}\right)\end{array}$ & $\begin{aligned} R^{2} & =0.31 \\
\mathrm{ADF} & =-7.44^{* * *}\end{aligned}$ \\
\hline \multirow{2}{*}{$\Delta i n d_{t}$} & I & $\begin{array}{c}8.966 \\
\left(2.15^{* *}\right)\end{array}$ & $\begin{array}{c}0.164 \\
\left(1.65^{*}\right)\end{array}$ & $\begin{array}{c}0.081 \\
\left(1.68^{*}\right)\end{array}$ & $\begin{array}{c}-0.037 \\
\left(-3.09^{* * *}\right)\end{array}$ & $\begin{aligned} R^{2} & =0.17 \\
\mathrm{ADF} & =-8.33^{* * *}\end{aligned}$ \\
\hline & II & $\begin{array}{c}6.859 \\
\left(2.01^{* *}\right)\end{array}$ & $\begin{array}{l}0.136 \\
\left(1.67^{*}\right)\end{array}$ & $\begin{array}{c}0.085 \\
\left(1.67^{*}\right)\end{array}$ & $\begin{array}{c}-0.037 \\
\left(-3.02^{* * *}\right)\end{array}$ & $\begin{aligned} R^{2} & =0.15 \\
\mathrm{ADF} & =-8.04^{* * *}\end{aligned}$ \\
\hline \multirow{2}{*}{$\Delta$ invest $_{t}$} & I & $\begin{array}{l}-11.179 \\
\left(-2.15^{* *}\right)\end{array}$ & $\begin{array}{c}0.162 \\
\left(1.79^{*}\right) \\
\end{array}$ & - & $\begin{array}{c}-0.065 \\
\left(-4.72^{* * *}\right) \\
\end{array}$ & $\begin{aligned} R^{2} & =0.24 \\
\mathrm{ADF} & =-7.85^{* * *}\end{aligned}$ \\
\hline & II & $\begin{array}{c}-8.428 \\
\left(-2.18^{* *}\right) \\
\end{array}$ & $\begin{array}{c}0.169 \\
\left(1.86^{*}\right) \\
\end{array}$ & - & $\begin{array}{c}-0.063 \\
\left(-4.54^{* * *}\right)\end{array}$ & $\begin{aligned} R^{2} & =0.24 \\
\mathrm{ADF} & =-7.88^{* * *}\end{aligned}$ \\
\hline \multirow{2}{*}{$\Delta$ cons $_{t}$} & I & $\begin{array}{l}-3.901 \\
(-1.24) \\
\end{array}$ & $\begin{array}{c}-0.197 \\
\left(-2.87^{* * *}\right)\end{array}$ & $\begin{array}{c}-0.115 \\
\left(-2.84^{* * *}\right)\end{array}$ & $\begin{array}{c}0.022 \\
\left(2.53^{* *}\right) \\
\end{array}$ & $\begin{aligned} R^{2} & =0.22 \\
\mathrm{ADF} & =-8.56^{* * *}\end{aligned}$ \\
\hline & II & $\begin{array}{l}-2.612 \\
(-1.03)\end{array}$ & $\begin{array}{c}-0.196 \\
\left(-2.78^{* * *}\right)\end{array}$ & $\begin{array}{c}-0.117 \\
\left(-2.87^{* * *}\right)\end{array}$ & $\begin{array}{c}0.021 \\
\left(2.42^{* *}\right)\end{array}$ & $\begin{aligned} R^{2} & =0.22 \\
\mathrm{ADF} & =-8.92^{* * *}\end{aligned}$ \\
\hline \multirow{2}{*}{$\Delta c p i_{t}$} & I & $\begin{array}{l}4.135 \\
(1.61)\end{array}$ & $\begin{array}{c}0.320 \\
\left(4.74^{* * *}\right)\end{array}$ & $\begin{array}{c}0.118 \\
\left(3.39^{* * *}\right)\end{array}$ & $\begin{array}{l}0.011 \\
(1.10)\end{array}$ & $\begin{aligned} R^{2} & =0.38 \\
\mathrm{ADF} & =-8.81^{* * * *}\end{aligned}$ \\
\hline & II & $\begin{array}{l}2.614 \\
(1.25)\end{array}$ & $\begin{array}{c}0.324 \\
\left(4.24^{* * *}\right)\end{array}$ & $\begin{array}{c}0.117 \\
\left(3.31^{* * *}\right)\end{array}$ & $\begin{array}{l}0.010 \\
(1.01)\end{array}$ & $\begin{aligned} R^{2} & =0.37 \\
\mathrm{ADF} & =-7.92^{* * *}\end{aligned}$ \\
\hline
\end{tabular}

Note: $t$-statistic in parentheses.

Source: author's calculations.

Regardless of the selected models, output volatility has a significant negative effect upon GDP and investment, while there is an opposite positive relationship 
between volatility and industrial production. In general, these results support wellknown arguments about an inverse relationship between volatility and investment due to unfavourable expectations or irreversibility of investment decisions (Bernanke, 1983; Ferrero, 2017; Carrière-Swallow \& Céspedes, 2013). However, our estimates for industrial production are in favour of treatment of output volatility as a proxy for productivity shocks in the economic environment of learning-by-doing (Annicchiarico, Corrado, \& Pelloni, 2011; Oikawa, 2010). The output volatility seems to be neutral with respect to consumption and consumer prices, being in accordance with the consumption smoothing hypothesis. Obviously, there is no support for the finding by Hoffmann et al. (2019) that investment reacts by less than consumption to the long-run volatility of output.

Using volatility measures from both $\mathrm{ARCH} / \mathrm{GARCH}$ models brings similar results across all regression models, but it is noteworthy that the statistically significant coefficients for volatility are considerably higher in the GARCH estimates than in the ARCH estimates. Moreover, it should be emphasized that the estimates with the variance from the EGARCH(1,1) model (not reported in the article but available on request) are not significantly different from those of the ARCH/GARCH models. The only difference worth mentioning is the higher value of estimated coefficients of output volatility across all specifications.

Among other results, the exchange rate depreciation has a positive impact on industrial production and investment, whereas the effect on GDP and consumption is negative. As expected, a weaker currency is the factor behind higher consumer price dynamics. In all specifications, the macroeconomic effects of commodity prices coincide with those of the exchange rate. The crisis developments of 2008-2009 and 2014-2015 affected both GDP and industrial production, with a strong negative effect upon investment activities as well.

Looking in greater detail at volatility sectoral effects (Table 3), it is clear that positive relationship between volatility and industrial production is achieved in the branches of manufacturing, food processing and power generation. It is worth noting that a positive link between volatility and TFP growth in manufacturing industries is highlighted in models with learning-by-doing in the research sector (Oikawa, 2010). For the steel-making industry, it appears that output volatility has a negative effect. One of the explanations could be the unfavourable effects of volatility under heavy reliance on external finance that lead to a decrease in productivity-enhancing investments, as argued by Aghion, Angeletas, Banerjee and Manova (2010). It cannot be ruled out that higher volatility creates credit supply shortages for steel manufacturers and thus decreases investment and output in the sector, in line with the arguments presented by Gete and Melkadze (2018).

Exchange rate depreciation is expansionary in three out of five industrial sectors. As expected, Ukrainian steel producers benefit from higher world prices for metals. The same positive correlation with the world metal prices does hold for the power generation industry. It is somewhat surprising that production in the oil and gas 
extraction sector is inversely related to the crude oil prices. As wheat prices contribute to the decrease in food production, it is an outcome suggesting the crowding out of domestic production by higher world market prices. As suggested by the crisis dummy, the manufacturing, power generation, oil and gas extraction sectors suffered most from the crisis developments, while the negative coefficients in the estimates for the steel-making and food-processing industries are not statistically significant.

Table 3. Determinants of sectoral output

\begin{tabular}{|c|c|c|c|c|c|c|}
\hline \multirow[b]{2}{*}{$\begin{array}{l}\text { Dependent } \\
\text { variable }\end{array}$} & \multirow[b]{2}{*}{ Model } & \multicolumn{4}{|c|}{ Independent variables } & \multirow[b]{2}{*}{ Statistics } \\
\hline & & Volatility & $\begin{array}{l}\text { Exchange } \\
\text { rate }\end{array}$ & $\begin{array}{c}\text { Commodity } \\
\text { prices }\end{array}$ & $\begin{array}{l}\text { Crisis } \\
\text { dummy }\end{array}$ & \\
\hline \multirow[b]{2}{*}{$\Delta i n d_{t}^{M A N}$} & I & $\begin{array}{l}25.178 \\
\left(2.56^{* *}\right)\end{array}$ & $\begin{array}{l}-0.278 \\
(-1.21)\end{array}$ & - & $\begin{array}{c}-0.104 \\
\left(-3.52^{* * *}\right)\end{array}$ & $\begin{aligned} R^{2} & =0.43 \\
\mathrm{ADF} & =-8.02^{* * *}\end{aligned}$ \\
\hline & II & $\begin{array}{l}14.456 \\
\left(1.74^{* *}\right)\end{array}$ & $\begin{array}{l}-0.267 \\
(-1.13)\end{array}$ & - & $\begin{array}{c}-0.094 \\
\left(-3.11^{* * *}\right)\end{array}$ & $\begin{aligned} R^{2} & =0.40 \\
\mathrm{ADF} & =-8.01^{* * *}\end{aligned}$ \\
\hline \multirow[b]{2}{*}{$\Delta i n d_{t}^{\text {STEEL }}$} & I & $\begin{array}{l}-12.549 \\
\left(-1.80^{*}\right)\end{array}$ & $\begin{array}{l}0.317 \\
\left(1.81^{*}\right)\end{array}$ & $\begin{array}{c}0.445 \\
\left(4.35^{* * *}\right)\end{array}$ & $\begin{array}{l}-0.025 \\
(-0.87)\end{array}$ & $\begin{array}{c}R^{2}=0.24 \\
\mathrm{ADF}=-10.89^{* * * *}\end{array}$ \\
\hline & II & $\begin{array}{c}-9.746 \\
\left(-1.87^{*}\right) \\
\end{array}$ & $\begin{array}{c}0.297 \\
\left(1.70^{*}\right) \\
\end{array}$ & $\begin{array}{c}0.437 \\
\left(4.31^{* * *}\right) \\
\end{array}$ & $\begin{array}{l}-0.023 \\
(-0.79)\end{array}$ & $\begin{array}{c}R^{2}=0.24 \\
\mathrm{ADF}=-10.30^{* * *}\end{array}$ \\
\hline \multirow[b]{2}{*}{$\Delta i n d_{t}^{F O O D}$} & I & $\begin{array}{c}13.338 \\
\left(2.67^{* * *}\right)\end{array}$ & $\begin{array}{l}-0.139 \\
(-1.40)\end{array}$ & $\begin{array}{l}-0.105 \\
\left(-2.37^{* *}\right)\end{array}$ & $\begin{array}{l}-0.008 \\
(-0.56)\end{array}$ & $\begin{aligned} R^{2} & =0.13 \\
\mathrm{ADF} & =-8.82^{* * *}\end{aligned}$ \\
\hline & II & $\begin{array}{c}11.945 \\
\left(3.01^{* * *}\right)\end{array}$ & $\begin{array}{l}-0.112 \\
(-1.11)\end{array}$ & $\begin{array}{c}-0.080 \\
\left(-1.83^{*}\right)\end{array}$ & $\begin{array}{l}-0.014 \\
(-0.99)\end{array}$ & $\begin{aligned} R^{2} & =0.15 \\
\mathrm{ADF} & =-7.92^{* * *}\end{aligned}$ \\
\hline \multirow[b]{2}{*}{$\Delta i n d_{t}^{\text {POWER }}$} & I & $\begin{array}{l}25.853 \\
\left(2.30^{* *}\right) \\
\end{array}$ & $\begin{array}{c}0.292 \\
\left(1.93^{*}\right) \\
\end{array}$ & $\begin{array}{c}0.251 \\
\left(2.13^{* *}\right) \\
\end{array}$ & $\begin{array}{c}-0.080 \\
\left(-3.08^{* * *}\right)\end{array}$ & $\begin{aligned} R^{2} & =0.18 \\
\mathrm{ADF} & =-7.52^{* * *}\end{aligned}$ \\
\hline & II & $\begin{array}{c}16.911 \\
\left(2.25^{* *}\right)\end{array}$ & $\begin{array}{c}0.312 \\
\left(2.07^{* *}\right)\end{array}$ & $\begin{array}{c}0.282 \\
\left(2.36^{* *}\right)\end{array}$ & $\begin{array}{c}-0.080 \\
\left(-3.08^{* * *}\right)\end{array}$ & $\begin{aligned} R^{2} & =0.18 \\
\mathrm{ADF} & =-7.24^{* * *}\end{aligned}$ \\
\hline \multirow[b]{2}{*}{$\Delta i n d_{t}^{\text {OIL }}$} & I & $\begin{array}{l}17.054 \\
\left(1.78^{*}\right)\end{array}$ & $\begin{array}{c}0.665 \\
\left(3.72^{* * *}\right)\end{array}$ & $\begin{array}{l}-0.126 \\
\left(-1.72^{*}\right)\end{array}$ & $\begin{array}{c}-0.110 \\
\left(-3.97^{* * *}\right)\end{array}$ & $\begin{aligned} R^{2} & =0.24 \\
\mathrm{ADF} & =-8.66^{* * *}\end{aligned}$ \\
\hline & II & $\begin{array}{l}8.306 \\
(1.08)\end{array}$ & $\begin{array}{c}0.681 \\
\left(3.73^{* * *}\right)\end{array}$ & $\begin{array}{l}-0.135 \\
\left(-1.88^{*}\right)\end{array}$ & $\begin{array}{c}-0.103 \\
\left(-3.64^{* * *}\right)\end{array}$ & $\begin{aligned} R^{2} & =0.22 \\
\mathrm{ADF} & =-8.74^{* * *}\end{aligned}$ \\
\hline
\end{tabular}

Source: author's calculations.

These estimates support negative and significant effect of output volatility on the money supply and the budget balance (Table 4). The lending rate decreases, while positive coefficients in the specification for the deposit rate are not important. Following the exchange rate depreciation, there is an increase in the lending rate and a decrease in the money supply. Both outcomes imply a tightening of monetary policy in the presence of downward exchange rate pressure. Higher commodity prices play a role in the decrease of the deposit rate and the improvement of the budget balance.

The policy implications are rather clear. In the presence of the output volatility, as in 2009 or 2014-2015, it is suggested to take discreet steps aimed at improving 
the budget balance in the first place, thus neutralizing the opposite effect of higher volatility on fiscal policy, especially if one assumes that output volatility used to be observed against the backdrop of falling commodity prices that amplifies the downward pressure on the budget balance. In contrast to the potentially stabilizing effects of an increase in the money supply, tightening of the fiscal policy does not raise inflationary concerns, which can be a cure worse than the disease. As output volatility is inversely related to production in the steel-making industry, temporary financial support should be provided to steel producers, with a focus upon sector-specific investments.

Table 4. Determinants of macroeconomic policy instruments

\begin{tabular}{|c|c|c|c|c|c|c|}
\hline \multirow{2}{*}{$\begin{array}{l}\text { Dependent } \\
\text { variable }\end{array}$} & \multirow[b]{2}{*}{ Model } & \multicolumn{4}{|c|}{ Independent variables } & \multirow[b]{2}{*}{ Statistics } \\
\hline & & Volatility & $\begin{array}{c}\text { Exchange } \\
\text { rate }\end{array}$ & $\begin{array}{c}\text { Commodity } \\
\text { prices }\end{array}$ & $\begin{array}{l}\text { Crisis } \\
\text { dummy }\end{array}$ & \\
\hline \multirow{2}{*}{$\Delta m 2_{t}$} & I & $\begin{array}{c}-6.762 \\
\left(-2.01^{* *}\right) \\
\end{array}$ & $\begin{array}{l}-0.104 \\
\left(-1.68^{*}\right) \\
\end{array}$ & - & $\begin{array}{c}-0.027 \\
\left(-2.54^{* *}\right) \\
\end{array}$ & $\begin{aligned} R^{2} & =0.49 \\
\mathrm{ADF} & =-7.82^{* * *}\end{aligned}$ \\
\hline & II & $\begin{array}{c}-5.421 \\
\left(-2.25^{* *}\right)\end{array}$ & $\begin{array}{c}-0.101 \\
\left(-1.62^{*}\right)\end{array}$ & - & $\begin{array}{c}-0.024 \\
\left(-2.30^{* *}\right)\end{array}$ & $\begin{aligned} R^{2} & =0.49 \\
\mathrm{ADF} & =-7.47^{* * *}\end{aligned}$ \\
\hline \multirow[b]{2}{*}{$\Delta r l_{t}$} & I & $\begin{array}{l}-16.283 \\
\left(-2.06^{* *}\right) \\
\end{array}$ & $\begin{array}{c}0.478 \\
\left(2.83^{* *}\right) \\
\end{array}$ & $\begin{array}{l}-0.103 \\
(-0.93) \\
\end{array}$ & $\begin{array}{c}-0.059 \\
\left(-1.91^{*}\right) \\
\end{array}$ & $\begin{aligned} R^{2} & =0.24 \\
\mathrm{ADF} & =-8.27^{* * *}\end{aligned}$ \\
\hline & II & $\begin{array}{l}-15.945 \\
\left(-2.69^{* * *}\right)\end{array}$ & $\begin{array}{c}0.606 \\
\left(3.10^{* * *}\right)\end{array}$ & $\begin{array}{l}-0.107 \\
(-0.97)\end{array}$ & $\begin{array}{c}-0.064 \\
\left(-2.12^{* *}\right)\end{array}$ & $\begin{aligned} R^{2} & =0.28 \\
\mathrm{ADF} & =-8.16^{* * *}\end{aligned}$ \\
\hline \multirow{2}{*}{$\Delta r d_{t}$} & I & $\begin{array}{l}3.314 \\
(0.22)\end{array}$ & $\begin{array}{l}0.140 \\
(0.47) \\
\end{array}$ & $\begin{array}{c}-0.363 \\
\left(-2.16^{* *}\right)\end{array}$ & $\begin{array}{l}-0.041 \\
(-0.98)\end{array}$ & $\begin{aligned} R^{2} & =0.09 \\
\mathrm{ADF} & =-7.36^{* * *}\end{aligned}$ \\
\hline & II & $\begin{array}{l}7.390 \\
(0.64) \\
\end{array}$ & $\begin{array}{l}-0.271 \\
(-0.82)\end{array}$ & $\begin{array}{c}-0.369 \\
\left(-2.28^{* *}\right)\end{array}$ & $\begin{array}{l}-0.014 \\
(-0.26)\end{array}$ & $\begin{aligned} R^{2} & =0.10 \\
\mathrm{ADF} & =-7.36^{* * *}\end{aligned}$ \\
\hline \multirow{2}{*}{$\Delta b d_{t}$} & I & $\begin{array}{l}-294.54 \\
\left(-1.75^{*}\right)\end{array}$ & $\begin{array}{l}1.998 \\
(1.48)\end{array}$ & $\begin{array}{c}5.336 \\
\left(2.36^{* *}\right)\end{array}$ & $\begin{array}{l}0.051 \\
(0.76)\end{array}$ & $\begin{aligned} R^{2} & =0.34 \\
\mathrm{ADF} & =-7.22^{* * *}\end{aligned}$ \\
\hline & II & $\begin{array}{l}-250.31 \\
\left(-1.86^{*}\right)\end{array}$ & $\begin{array}{l}2.735 \\
(0.36)\end{array}$ & $\begin{array}{c}5.273 \\
\left(2.37^{* *}\right)\end{array}$ & $\begin{array}{l}0.462 \\
(0.70)\end{array}$ & $\begin{aligned} R^{2} & =0.34 \\
\mathrm{ADF} & =-7.22^{* * *}\end{aligned}$ \\
\hline
\end{tabular}

Source: author's calculations.

Generally, investment should be given priority not only during any stabilization efforts, but also in the wider context of long-term macroeconomic decision-making. In this respect, higher output volatility can be useful as a factor behind a decrease in the lending rate. Despite the favourable impact on industrial production, the merits of exchange rate depreciation as another policy tool seem to be counterproductive in cases of higher output volatility. First, industrial production is not affected by output volatility (except for steel-making), so there is no need to boost production levels by a weaker currency. Second, exchange rate depreciation contributes to a decrease in both consumption and GDP as a whole, thus deepening the output slump caused 
by its higher volatility. Finally, exchange rate depreciation is inflationary and it increases the lending rate, thus worsening the prospects of GDP growth.

\section{Conclusions}

This paper provides empirical analysis of the macroeconomic effects of output volatility in Ukraine with the application of the conditional volatility of the GDP from the ARCH/GARCH models as a measure of instability. The results indicate that the negative growth effects of output volatility are partially offset by the positive impact of volatility on industrial production. Output volatility has expansionary effects on three out of five sectors (manufacturing, food processing and power generation), with a likely negative impact only on the steel-making industry. Exchange rate depreciation contributes to an increase in industrial production and investment, but at the expense of higher inflation and weaker consumption. As expected, exchange rate depreciation implies a decrease in the money supply and an increase in the lending rate. However, both monetary indicators are not affected by the commodity prices. Output volatility is associated with lower money supply and decrease in the lending rate, with a negative impact on the budget balance.

In the case of higher output volatility, it is suggested to improve the budget balance for stabilization purposes, while avoiding both monetary supply expansion and exchange rate depreciation. As industrial production is not affected by output volatility (except for steel-making), exchange rate depreciation is likely to provide excessive demand stimuli, while contributing to a decrease in both consumption and GDP as a whole. Exchange rate depreciation is inflationary and it increases the lending rate, thus worsening prospects of GDP growth in both the short and long term.

\section{References}

Aghion, P., Angeletos, G.-M., Banerjee, A., \& Manova, K. (2010). Volatility and growth: Credit constraints and the composition of investment. Journal of Monetary Economics, 57(3), 246-265.

Alimi, N. (2016). Volatility and growth in developing countries: An asymmetric effect. The Journal of Economic Asymmetries, 14(PB), 179-188.

Antonakakis, N., \& Badinger, H. (2016). Economic growth, volatility, and cross-country spillovers: New evidence for the G7 countries. Economic Modelling, 52(PB), 352-365.

Annicchiarico, B., Corrado, L., \& Pelloni, A. (2011). Long-Term Growth and Short-Term Volatility: The Labour Market Nexus. Manchester School, 79(s1), 646-672.

Bernanke, B. (1983). Irreversibility, Uncertainty, and Cyclical Investment. The Quarterly Journal of Economics, 98(1), 85-106.

Berument, H. M., Dincer, N., \& Mustafaoglu, Z. (2012). Effects of growth volatility on economic performance - Empirical evidence from Turkey. European Journal of Operational Research, 217(2), 351-356.

Caporale, T., \& McKiernan, B. (1996). The relationship between output variability and growth: evidence from post-war UK data. Scottish Journal of Political Economy, 43(2), 229-236. 
Carrière-Swallow, Y., \& Céspedes, L. F. (2013). The impact of uncertainty shocks in emerging economies. Journal of International Economics, 90(2), 316-325.

Choi, S., Furceri, D., Huang, Y., \& Loungani, P. (2018). Aggregate uncertainty and sectoral productivity growth: The role of credit constraints. Journal of International Money and Finance, $88(\mathrm{C})$, 143-158.

Ferrero, D. (2017). Volatility and slow technology diffusion. European Economic Review, 96(1), 18-37.

Fountas, S., Karanasos, M., \& Mendoza, A. (2004). Output variability and economic growth: The Japanese case. Bulletin of Economic Research, 56(4), 353-366.

Friedman, M. (1968). The role of monetary policy. American Economic Review, 58(1), 1-17.

Garcia-Herrero, A., \& Villarubia, J. (2007). The Laffer curve of macroeconomic volatility and growth: Can it be explained by the different nature of crises? Money Affairs, 44, 43-60.

Gete, P. \& Melkadze, G. (2018). Aggregate volatility and international dynamics. The role of credit supply. Journal of International Economics, 111(1), 143-158.

Güreşçi, G. (2018). Effects of macroeconomic volatility on economic growth: Evidence from the European Union. International Journal of Management Economics and Business, 14(3), 591-599.

Hnatkovska, V., \& Loayza, N. (2005). Volatility and growth. In J. Aizenman \& B. Pinto (Eds.), Managing economic volatility and crises: A practitioner's guide (pp. 65-100). Cambridge: Cambridge University Press.

Hoffmann, M., Krause, M., \& Tillmann, P. (2019). International capital flows, external assets and output volatility. Journal of International Economics, 117(2), 242-255.

Imbs, J. (2007). Growth and volatility. Journal of Monetary Economics, 54(7), 1848-1862.

Lensink, R., Bo, H., \& Sterken, E. (1999). Does uncertainty affect economic growth? An empirical analysis. Review of World Economy / Weltwirtschaftliches Archive, 135(3), 379-396.

Oikawa, K. (2010). Uncertainty-driven growth. Journal of Economic Dynamics \& Control, 34(5), 897-912.

Posch, O. (2011). Explaining output volatility: The case of taxation. Journal of Public Economics, 95(11), 1589-1606.

Ramey, G., \& Ramey, V. (1995). Cross-country evidence on the link between volatility and growth. The American Economic Review, 85(5), 1138-1151.

Speight, A. (1999). UK output variability and growth: Some further evidence. Scottish Journal of Political Economy, 46(2), 175-184. 